agreement with each other which the results show, and they take this as evidence that the movements of the rod are due to subjective and not to objective causes. These are precisely the opinions formed as a result of my own series of experiments; and it may still be assumed that no adequate evidence has been produced in favour of the existence of something acting outside the dowser which causes his twig or other indicator to move when it is over water.

In La Nature for May Io (p. .379), M. Gustave Le Bon has published an article recording the success of certain diviners in discovering the metals contained in five envelopes (viz., aluminium, copper, silver, lead, and zinc); but, as he admits, the method of experiment was not satisfactory, since he thinks he may unintentionally have given signs of approval while the diviners consulted together as to what metals were contained in the envelopes, and since the method of procedure involved the displacement of the envelopes by the diviners, thus giving them an opportunity of forming an opinion based on the different weights, \&c., of the metals. He also mentions that M. Coupaux, who performed similar experiments, only had one success out of five, but that the diviners objected to these experiments because the metals were enclosed in glass tubes, and, as they allege, the glass prevents their feeling the influence of the metals.

On the whole, M. Le Bon is of opinion that there is enough evidence to warrant further examination into the claims of diviners; he thinks, however, that the commission appointed by the Académie des Sciences to examine into the question so far as it relates to the discovering of springs ought to do more, and he asks that this commission may also undertake experiments similar to those which he has performed. My own experiments in this direction went to show that the experienced diviners with whom they were tried were not able to discover gold or silver by means of their rods; for though one diviner scored a remarkable success in a single instance, he was absolutely wrong in the other experiments of the same kind which he performed. Nevertheless, this single success (fortuitous as I believe) confirmed an intelligent friend who witnessed it in his belief that the powers of the diviners are real!

J. WERTHEIMER.

\section{DR. P. L. SCLATER, F.R.S.}

7 OOLOGISTS throughout the world will join with their English brethren in lamenting the death on June 27 -albeit at the advanced age of eighty-four-of Dr. Phillip Lutley Sclater, F.R.S. The second son of the late Mr. W. L. Sclater, of Hoddington House, Hants, the deceased naturalist was born in 1829 , and received his education first at Winchester and subsequently at Corpus Christi College, Oxford, where he graduated first class in mathematics, and subsequently became honorary fellow of his college. In 1855 he was NO. 2279, VOL. 9I] called to the Bar as a member of Lincoln's Inn, and in 1875 he acted as private secretary to his brother, the Hon. G. Sclater-Booth (afterwards Lord Basing), when President of the Local Government Board. So early as $185^{\circ}$ he had commenced to write on zoology. Soon after his call to the Bar he devoted himself mainly to natural history, and he was elected secretary to the Zoological Society of London in 1859 , which important post he retained till I902, when advancing years led to his voluntary resignation.

During the greater part of that prolonged period Dr. Sclater was the ruling spirit of the society, and it was to his organising capacity and untiring energy that the menagerie in Regent's Park attained the pre-eminent position it occupied, both as a zoological centre and a place of popular resort, at the time of his retirement. He was also editor of the society's numerous publications, to which he communicated an extraordinary number of valuable papers and memoirs; and it was during his term of office that the Proceedings became entitled to rank as one of the very foremost zoological journals in the world.

But the executive and scientific work connected with the Zoological Society by no means sufficed to absorb all the energies of its secretary, for in I 859 he became editor of the Ibis, a then newly started ornithological journal, and held that post until $186_{5}$, to resume it, in conjunction with the late Mr. Howard Saunders, in I88,3, and to hold it, either alone or associated with others, throughout the rest of his working career. Dr. Sclater was also one of the founders of the British Ornithologists' Union, of which body he long occupied the presidential chair. Of even more importance, perhaps, was Dr. Sclater's share in the foundation and maintenance of the "Zoological Record," as without that wonderful work of reference zoology at the present day would be an absolute impossibility.

Dr. Sclater was also one of the pioneers-if not the actual founder-of the modern science of geographical distribution; and it is to him that we owe such now familiar terms as "Palæarctic" and "Nearctic," which are excellent examples of the classic form of scientific nomenclature in which he delighted.

The prodigious amount of scientific work, more especially in ornithology, produced by Dr. Sclater may be inferred from the fact that a record of his career published some years ago contains entries of something like I 200 different papers and memoirs. From a popular point of view one of the most attractive works with which he was connected was Wolf's "Zoological Sketches," while his monographs of various groups of South American birds are models of their kind.

For the greater part of his long life Sclater was a man of intense activity and energy, and only during the last few years did he show signs of failing health. Injuries received in a carriage accident a few weeks ago hastened the termination of a long life devoted to the advancement of zoological science.
R. L. 